\title{
Story Factory: A Tool for Building Whole Language Skills and a Whole Lot More
}

$\mathrm{T}$ he late great Albert Einstein has been quoted as saying: "To raise a smart child, tell him stories. To raise a smarter child, tell him more stories." While this advice makes good sense to anyone who has worked with storytelling in education, I would add another sentence: "To raise even smarter children, help them tell their own stories."

Creating and performing their stories provides children with remarkable benefits, including:

- Empowerment: It has been said that we are all the world's foremost experts on only one topic: Our own lives. How much more meaningful that point is with respect to children, who are taught by others for so much of their day. When children tell their stories, no one can correct them. What is more, they are planting their own images in their listeners' brains - an amazingly powerful experience for any teller.

- Increased self-esteem: Empowerment contributes to self-esteem. There are few better feelings than having our peers honor us by really listening. And if the story is successful, they will do just that.

- Whole language skills: The request to tell something "in your own words" requires vocabulary, grammar, syntax, organization and other tools. Storytelling is an enjoyable way to practice these skills, so there is more incentive to use them correctly. What is more, by turning on students to narrative, oral storytelling enhances literacy.

- Imagination: Take away the computer, take away the television

\section{Caren S. Neil}

and video games, take away, even, the books, and you've got a child and a brain to rely on for entertainment. When children learn to use their imagination through storytelling, they grow up to use it to imagine alternatives in all sorts of life situations, from conflict resolution at work to parenting at home.

- Interpersonal skills: Speaking of conflict resolution, what better way to help teach children tolerance and remove social barriers than by giving them an opportunity to walk in each other's shoes through personal storytelling? When we see something through the eyes of another, we can never again view that person as an "Other."

Now that we know why to encourage children to tell their stories, it is time to discuss how. I call my technique Story Factory, because it offers children a blueprint from which to craft their tales. It is loosely based on work on narrative by linguists Labov and Waletzky (1967).

\section{Step One:}

First, I ask the class what makes a story. The great master storyteller and author Kendall Haven (2002) uses a game called "Is it a story yet?" I might ask, "What makes something a story?" Someone could say, "People." Next I ask for two facts about a character - a boy named Joe, or a little black dog. Then I ask, "Is it a story yet?" Most children will know that it is not. I continue with setting (a haunted house at midnight), dialogue ("I'm scared!"), or whatever else they mention. I write their responses on the board. Many children will instinctively know when we have created a story, even if they do not yet know why.

\section{Step Two:}

I write the words beginning, middle and end on another space on the board- or else one or two of the three, and they fill in the others. We discuss what the words mean in terms of story, that is, that every story has a beginning, middle and end. I ask them to find the beginning, middle and end of the simple story outline we have just written on the board.

\section{Step Three:}

Now, back to our written contributions to "Is it a story yet?." Alongside the character descriptions, I write, Who. (Who is the story about.) Alongside the setting, I write Where and When. Alongside the problem or challenge for the main character, I write What. (What is the problem.) Alongside the solution, I write How. (How is the program resolved.) The children are often able to help me fill these in. Sometimes I simply write who, what, where, when and how on the board and ask them to place the words in the appropriate locations in the story.

\section{Step Four:}

Next, I ask them why the different elements appear when they do in the story. For example, we need to know something about the who in the beginning in order to know whom to care about. In our own lives, we care about ourselves and our family and friends, because we know them best. We need to get to know the person (or animal) in the story in order to care what happens to him or her.

For slightly older children, I add in why to the middle section 
of the story. Why means why should I care? In other words, what is at stake? ("I woke up late for school." Why is that important? "I knew I'd get in big trouble if I missed the bus again this week.")

\section{Step Five:}

Then I review the parts of the story, beginning, middle and end, and the who, where, when, what, (why) and how elements. We now do a group story creation based on these building blocks. It comes much easier to the children now that they have the prompts.

\section{Step Six:}

Finally, it is time for the children's own stories. The most effective way I've found of getting students started with fictional stories is to pass out pictures of scenes - paintings or advertisements. It's even better when the scenes are displayed on a wall, as in a museum, so the whole group can see. I have actually watched four-year-olds act as museum docents, telling the group the story of the picture they have chosen. I might also hand out common items, like a key, or a wallet, or a cup and ask them to tell a story containing that item.

In order to encourage personal stories, I give out handouts with story ideas that are not too vague yet not too specific, such as: a time my pet got punished, or the best time I had with my sibling. For older children, I ask them to fill in sense details as they tell their stories, such as what the haunted house smelled like or how the spider web tasted.

You will find that Story Factory provides a good time for all - even the teacher. And it is a wonderful learning experience.

\section{Works Cited}

Haven, K. 2002. Workshop presentation at National Storytelling Network an- nual conference. Providence, Rhode Island, July.

Labov, W. and J. Waletzky. 1967. "Narrative analysis: Oral versions of personal experience". In Essays on the verbal and visual arts: Proceedings of the 1966 annual spring meeting of the American Ethnological Society. Seattle: University of Washington Press. pp. 12-44.

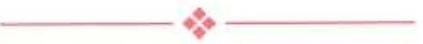

Caren S. Neile, MFA, Ph.D., is founding director of the South Florida Storytelling Project at Florida Atlantic University. Dr.

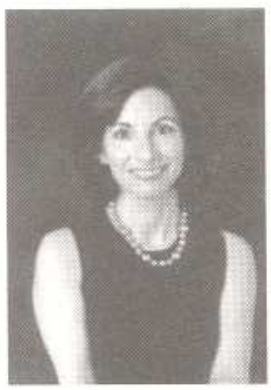
Neile serves on the national board of the Healing Story Alliance and is a consultant to the International Storytelling Center. She is managing editor of Storytelling, Self, Society: An Interdisciplinary

Journal of Storytelling Studies. www.fau.edu/storytelling/ journal.htm.

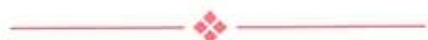

\section{Storytelling Sites on the WEB}

There are numerous resources on the WEB. Many references are provided by our authors. Two not mentioned in the articles are noteworthy.

\section{Story Arts}

This site is a must for Teachers who are interested in using stories and storytelling in their classroom activities. Featured are sections about storytelling across the curriculum including stories for science, math and social studies, using folktales in the classroom, lesson plans and worldwide, exciting, informative links to a broad spectrum of resources. Included is an impressive list of storytelling books for teachers.

A special page provides links to concise folk stories that teachers can use to "tell". Plots for student retelling are also included.

Teachers can subscribe to a newsletter page.
Heather Forest has given permission to provide her website and email address.

It is www.storyarts.org or you can email

heather@storyarts.org

\section{A second sure hit is Heartland Story League}

This site based out of Chicago, provides numerous links to such sites as translations of Aesop's tales, Celtic legends, Folklore, Myth and Legend for children, Scottish Folklore, Handbook for Storytellers, Christian and Hasidic stories for telling, the Internet public library and so on. You can join for a small fee, read the newsletters and contribute through the WEB. This site is never ending and for would be storytellers is a joy to travel. Your students will have fun and your storytelling will improve.

Visit the site at

http://geocities.com/heartland98.geo 